\title{
Histomorphological spectrum of eyelid lesions-A 6 year retrospective study
}

\author{
Giri Punja M. ${ }^{1}$, Bharathi M. ${ }^{2}$, Shashidhar H.B. ${ }^{3}$ \\ ${ }^{1}$ Dr. Giri Punja M, Tutor, ${ }^{2}$ Dr. Bharathi M., Professor and HOD, ${ }^{3}$ Dr. Shashidhar H.B., Professor, All authors are \\ affiliated with Mysore Medical College and Research Institute, Mysore, Karnataka, India
}

Corresponding Author: Dr. Giri Punja M., Tutor, Mysore Medical College and Research Institute, Mysore, Karnataka, India.giripunja@yahoo.com

\begin{abstract}
Background: Eyelid lesions are encountered by all primary care physicians and Ophthalmologists. Histology of eyelid comprises various components and structures that give rise to a wide spectrum of pathologies. The clinical presentation of eyelid lesions is myriad with benign lesions masquerading malignant tumours. Though eyelid lesions are fairly common in Indian subcontinent, there is paucity of reports in Indian literature. This study was undertaken to characterize the distribution of various eyelid lesions and clinicopathological correlation in a tertiary care centre of South India. Objectives: To retrospectively carry out a clinicopathological analysis of eyelid lesions requiring surgical excision in the Department of Pathology of a tertiary care centre in South India. Methods: A retrospective review of clinicopathological profile of excised eyelid lesions diagnosed in our tertiary care centre was done. Clinicopathological data were retrieved from patient's clinical records and biopsy reports. Result: Among 219 eyelid lesions, 192 were benign lesions and 27 were malignant tumours. The most common eyelid lesion was dermoid cyst (69 cases) followed by Nevus (32 cases) and Pyogenic Granuloma (12 cases). The most common malignant eyelid lesion was Sebaceous Cell Carcinoma (13 cases). Conclusion: Dermoid cyst and Nevus are the most common eyelid lesions requiring biopsy and sebaceous cell carcinoma is the most common malignant eyelid tumour. All surgically excised eyelid lesions must be subjected to histopathological examination without fail to provide a definitive diagnosis, continued patient care and management.
\end{abstract}

Keywords: Eyelid, Dermoid cyst, Histopathology, Sebaceous Cell Carcinoma

\section{Introduction}

Eye is a vital visual organ. Eyelids cover and protect the human eye and are an essential part of the human face. The eyelids are formed by the reduplication of the surface ectoderm above and below the cornea. Eyelids being specialised regions of the eye and ocular adnexa, consist of multiple tissue types including epithelial, vascular, adnexal, histiocytic, neural and melanocyticorigin $[1,2]$.

Lesions of eyelid are common concerns amongst patients and are affected by wide range of benign and malignant lesions which could be aesthetically disturbing to the patient as well as diagnostically challenging to the attending Ophthalmologist. Eyelid tumours represent $15 \%$ of face tumours and about 5$10 \%$ of skin tumours $[1,3,4]$. Apart from Pathologists, many Internists, family physicians and skin specialists are often requested to determine if a lesion is benign or

Manuscript received: $10^{\text {th }}$ December 2018

Reviewed: $20^{\text {th }}$ December 2018

Author Corrected: $27^{\text {th }}$ December 2018

Accepted for Publication: $31^{\text {st }}$ December 2018 malignant. Eyelid tumours are by far the most commonly encountered neoplasm in Ophthalmology clinics. Unawareness or ignorance of these lesions can result in debility, visual compromise, facial disfigurement and its attendant psychosocial impact. The diagnosis of diseased eyelid lesions plays a very important role in patient care [5].

We have undertaken this study to determine the histopathological spectrum of eyelid lesions to contribute to the literature information regarding different eyelid lesions and tumours received in our tertiary care setup.

\section{Methods}

Type of study and Place of Study: Retrospective eyelid pathology data reviewed over the past 6-years. Allthe eyelid biopsies received in the Department of Pathology, Mysore Medical College and Research Institute, Mysore from June 2012 to June 2018 were retrospectively reviewed.

Pathology Update: Tropical Journal of Pathology \& Microbiology Available online at: www.pathologyreview.in 586 | P a g e 


\section{Original Research Article}

Sample collection and sampling methods: A total of 219 eyelid biopsies were obtained from patients attending the Department of Ophthalmology of our Institute.

Inclusion criteria: All the eyelid biopsies were studied as per epidemiological and histomorphological data.

The demographics (age, sex), clinical features (laterality, tumour topography), indications for biopsies, clinical diagnosis and the histopathological diagnosis were noted. The original slides were retrieved and reviewed; fresh sections were cut from tissueparaffin blocks wherever necessary and stained by routine hematoxylin and eosin stains. Special stains such as $\mathrm{PAS}, \mathrm{ZN}$ stain etc. were done as and when required.

\section{Exclusion criteria: None}

Statistical methods: The statistical analysis was done using SSPS version 16.0. This study received the approval of Institutional Ethical Committee.

\section{Results}

A total of 219 eyelid biopsies were reviewed during the 6 year retrospective study period. Eyelid lesions constituted $34.43 \%$ of total ophthalmic biopsies (636 cases) during this interval. The patients presenting with eyelid lesions ranged in age from 1 year to 86 years, the most common age group was 31-40 years followed by 21-30 years and 41-50 years. Eyelid lesions were significantly rare after 80years of age [Table1].

Table-1: Age wise distribution of eyelid lesions.

\begin{tabular}{|c|c|c|}
\hline Age ( in years ) & No of cases (total=219) & In Percentage \% \\
\hline $0-10$ & 19 & 8.67 \\
\hline $11-20$ & 22 & 10.04 \\
\hline $21-30$ & 34 & 15.52 \\
\hline $31-40$ & 41 & 18.72 \\
\hline $41-50$ & 33 & 15.06 \\
\hline $51-60$ & 28 & 14.62 \\
\hline $61-70$ & 32 & 3.19 \\
\hline $71-80$ & 7 & 1.36 \\
\hline $81-90$ & 3 & \\
\hline
\end{tabular}

There was no sex preponderance in the distribution of eyelid lesions (males=109; females=110) with a ratio of 1:1. Eyelid lesions were more common on the left eye (117, 53.42\%). However there was no evident left- sided or right-sided preference seen among the most individual tumours. Upper eyelid was involved in 146 cases (66.66\%) which was significantly more common than lower eyelid involved in 73 cases (33.34\%). Ethnicity of the patients was not specifically identified.

Pediatric cases of age less than 12 years constituted 9.58\% (21) cases, most of which were benign cystic lesions which included Dermoid cyst and Retention cyst. Among a total of 219 lesions, 192cases (87.67\%) were benign tumors and $27(12.33 \%)$ were malignant tumors.

The most common benign eyelid lesion was dermoid cyst (69) followed by nevus (intradermal nevus=26 and compound nevus=6), pyogenic granuloma, dermolipoma, retenrtion cyst, hemangioma, squamous papilloma and chalazion.

We encountered 5 cases of granulomatous lesions among which 1 case showed positivity for acid fast bacilli on Zeil Neilson special stain, a diagnosed case of Tuberculosis. There were 4 cases of Molluscum contagiosum, 3 of which involved both the upper and lower eyelids.

There were 2 cases each of foreign body giant cell reaction, hamartoma, angiofibroma, pilamatricoma, fibromatosis, syringocystadenoma papilleferum, sebaceous adenoma, trichoepithelioama and apocrine hydrocystoma.

Rare cases included eccrine spiradenoma, neurofibroma, tubular apocrine adenoma, steatocystoma simplex, sebaceous epithelioma, benign fibrous histiocytoma, apocrine adenoma and lymphangioma simplex (one case each) [Table 2]. 


\section{Original Research Article}

Table-2: Pattern of common benign eyelid lesions.

\begin{tabular}{|l|c|}
\hline Benign eyelid lesions & Number of cases(Total=192) \\
\hline Dermoid cyst & 69 \\
\hline Intradermal nevus & 26 \\
\hline Compound nevus & 6 \\
\hline Pyogenic granuloma & 12 \\
\hline Dermoliopma & 11 \\
\hline Retention cyst & 10 \\
\hline Hemangioma & 9 \\
\hline Squamous papilloma & 7 \\
\hline Chalazion & 7 \\
\hline Granulomatous lesion & 5 \\
\hline Molluscum contagiosum & 4 \\
\hline
\end{tabular}

Among 27 malignant eyelid tumors, Sebaceous cell carcinoma (13 cases) was the commonest tumor followed by basal cell carcinoma $(n=5)$. Rare malignant eyelid lesions were Malignant chondroid syringoma and Spindle cell sarcoma, one case each [Table 3]. Malignant eyelid tumors showed a female sex preponderance (females $=17$; males $=10$ ) and were more common in upper eyelids (16 cases). However all 3 cases of Basal cell carcinoma in this study involved lower eyelids.

Table-3: Pattern of Malignant eyelid tumours

\begin{tabular}{|l|c|}
\hline Malignant eyelid lesions & Number of cases(Total = 27) \\
\hline Sebaceous cell carcinoma & 13 \\
\hline Basal cell carcinoma & 5 \\
\hline Squamous cell carcinoma & 4 \\
\hline Malignant melanoma & 2 \\
\hline Non-Hodgkin lymphoma & 1 \\
\hline Malignant chondroid syringoma & 1 \\
\hline Spindle cell sarcoma & 1 \\
\hline
\end{tabular}

Among all the eyelid lesions, the clinical diagnosis correlated with final histopathological diagnosis in 149 cases (68\%).

\section{Discussion}

Eyelid histology comprises of various structures that gives rise to wide spectrum of pathologies the diagnosis of the disease plays an important role in patient care. However there exists a variation in the pattern and frequency on the basis of geographical locations many benign tumours have a tendency to masquerade malignant lesions. Although the incidence of eyelid malignancies is increasing, their global distribution is varied and remains largely under characterised and under described.

Literature search has revealed variable prevalence of benign and malignant eyelid tumours in different geographical locations. The observation and results of the present study were compared with observations of various other similar studies and the findings are as follows:

The overall sex distribution of benign eyelid tumours showed no significant gender preponderance in the present study which was comparable with studies by Sushma TA et al and Al-Faky YH et al $[1,6]$. Dermoid cyst was the most common eyelid lesion comparable with Gupta P et al, Sushma TA et al, Sanjay CC et al and Mohan BP et al[7, 1,5,8]. Benign lesions constitute the majority of eyelid lesions [Table 4], [Table 5]. 


\section{Original Research Article}

Table-4: Comparison of incidence of Benign and Malignant eyelid lesions in various studies.

\begin{tabular}{|c|c|c|}
\hline Studies & Benign & Malignant \\
\hline $\begin{array}{l}\text { Tesluk GC et al [9] } \\
\text { (1985) }\end{array}$ & $79 \%$ & $21 \%$ \\
\hline $\begin{array}{l}\text { Abdi U et al [10] } \\
\text { (1996) }\end{array}$ & $58.90 \%$ & $41.41 \%$ \\
\hline $\begin{array}{l}\text { Obata } \mathrm{H} \text { et al }[11] \\
\qquad(2005)\end{array}$ & $73 \%$ & $27 \%$ \\
\hline $\begin{array}{c}\text { Mondal SK et al [2] } \\
(2008)\end{array}$ & $60 \%$ & $40 \%$ \\
\hline $\begin{array}{c}\text { Sanjay CC et al [5] } \\
(2009)\end{array}$ & $79 \%$ & $12 \%$ \\
\hline $\begin{array}{c}\text { Coroi MC et al [12] } \\
(2010)\end{array}$ & $44 \%$ & $56 \%$ \\
\hline $\begin{array}{l}\text { Paul S et al [13] } \\
\text { (2011) }\end{array}$ & $75.9 \%$ & $24.1 \%$ \\
\hline $\begin{array}{l}\text { Shaikh IY et al [3] } \\
\text { (2012) }\end{array}$ & $78.1 \%$ & $21.9 \%$ \\
\hline $\begin{array}{l}\text { Mary Ho et al [14] } \\
(2013)\end{array}$ & $86 \%$ & $14 \%$ \\
\hline $\begin{array}{c}\text { Ramya et al [15] } \\
\text { (2014) }\end{array}$ & $52.3 \%$ & $47.7 \%$ \\
\hline $\begin{array}{c}\text { Huang YY et al [16] } \\
(2015)\end{array}$ & $95 \%$ & $5 \%$ \\
\hline $\begin{array}{c}\text { Garima MA et al [17] } \\
\text { (2018) }\end{array}$ & $69.56 \%$ & $30.44 \%$ \\
\hline $\begin{array}{c}\text { Sushma TA et al[1] } \\
(2018)\end{array}$ & $92.67 \%$ & $7.24 \%$ \\
\hline Present study 2018 & $87.67 \%$ & $12.33 \%$ \\
\hline
\end{tabular}

As evident from the above table, benign eyelid lesions are by far more common than the malignant ones.

Table-5: Comparison of incidence of common malignant eyelid tumors in various studies

\begin{tabular}{|c|c|c|c|}
\hline Eyelid tumours & $\begin{array}{c}\begin{array}{c}\text { Sebaceous cell } \\
\text { carcinoma }\end{array} \\
\end{array}$ & $\begin{array}{c}\text { Basal cell } \\
\text { carcinoma }\end{array}$ & $\begin{array}{c}\text { Squamous cell } \\
\text { carcinoma }\end{array}$ \\
\hline $\begin{array}{c}\text { Jahagirdhar et al [18] } \\
(2007)\end{array}$ & 37 & 44.5 & 14 \\
\hline $\begin{array}{c}\text { Kumar R et al [4] } \\
(2008)\end{array}$ & 28.6 & 28.6 & 38.1 \\
\hline $\begin{array}{l}\text { Coroi MC et al [12] } \\
(2010)\end{array}$ & 19.6 & 72.55 & 1.96 \\
\hline $\begin{array}{l}\text { Farhat F et al [19] } \\
\qquad(2010)\end{array}$ & 14.94 & 56.32 & 20.69 \\
\hline $\begin{array}{l}\text { Kale SM et al [20] } \\
\qquad(2012)\end{array}$ & 31.2 & 48.2 & 13.7 \\
\hline $\begin{array}{c}\text { Gupta P et al [7] } \\
(2012)\end{array}$ & 44.4 & 11.1 & 22.2 \\
\hline $\begin{array}{l}\text { Mary Ho et al [14] } \\
(2013)\end{array}$ & 7.1 & 42.9 & 17.9 \\
\hline $\begin{array}{l}\text { Ramya et al [15] } \\
(2014)\end{array}$ & 41.4 & 26.8 & 21.9 \\
\hline $\begin{array}{l}\text { Huang YY et al [16] } \\
(2015)\end{array}$ & 21.1 & 57.8 & 10.1 \\
\hline $\begin{array}{l}\text { Kafle SU et al } 2016 \text { [21] } \\
(2016)\end{array}$ & $6.26 \%$ & $25 \%$ & $15.62 \%$ \\
\hline $\begin{array}{c}\text { Gupta Y et al [22] } \\
(2017)\end{array}$ & 52.1 & 10.41 & 12.5 \\
\hline Present study 2018 & 48.14 & 18.5 & 14.81 \\
\hline
\end{tabular}




\section{Original Research Article}

Sebaceous gland carcinoma arises from gland of Zies, Meibomian glands and sebaceous glands of caruncle and eyebrow. Incidence of Sebaceous gland carcinoma in eyelid shows geographical variation. However, recent studies have shown that Sebaceous gland carcinoma is the most common malignant eyelid tumour in Indian population and other Asian countries, which is supported by our present study. In Western countries, Basal cell carcinoma is the commonest malignant eyelid tumour accounting for $80-90 \%$ of eyelid cancers followed by Squamous cell carcinoma and Sebaceous gland carcinoma $[1,7]$.

Increased incidence of Sebaceous gland carcinoma and reduced Basal cell carcinoma might be attributed to oily skin and more melanin pigment in Indian population. At the same time, a decline in basal cell carcinoma and squamous cell carcinoma can be due to increased melanin which provides protection from damaging sunrays.

Sebaceous gland carcinoma was more common in females and upper eyelid in the present study and same results were shown in studies by Sushma TA et al, Mary HO et al, Kale SM et al, Kaliki S et al and Wang JC et al, justifying the fact that Sebaceous glands are more in upper eyelids than lower eyelids[1,14,20,24,23]. Lin et al described a significantly higher incidence of Sebaceous gland carcinoma in Taiwan [25].

Sebaceous gland carcinoma are aggressive lethal tumours and can recur in 6-29\% cases [1]. Henceforth high degree of suspicion and accurate clinicopathologic diagnosis is of atmost importance in our Asian population.

Limitation: Those cases where the reviewed slide diagnosis were different from the earlier diagnosis have not been included in this study.

\section{Conclusion}

This 6-year retrospective histopathological study of eyelid lesions has shown Dermoid cyst as the most common eyelid lesion followed by Nevus (Intradermal and Compound Nevus). Rare lesions include neurofibroma, eccrine spiradenoma, lymphangioma simplex to name a few. Sebaceous cell carcinoma was the commonest eyelid malignancy. Recurrent lesions and even innocent looking lesions could be aggressive malignancies or their precursors.

Eyelid lesions being largely under-characterised and under-distributed in our Indian population, early diagnosis and proper management helps in reducing the debility and loss of vision of patients and also help the attending ophthalmologists in shaping apt strategy for the diagnosis and management of eyelid neoplasm.

What this study adds to existing knowledge: Dermoid cyst followed by Nevus is the commonest eyelid lesions. Though benign lesions are common among the eyelid lesions, all eyelid lesions must be sent for histopathological examination to rule out the more dangerous malignant tumours.

Funding: Nil, Conflict of interest: None initiated Permission from IRB: Yes

\section{References}

1. Sushma, T.A., Thejaswini, M.D., Suguna, B., \& Dharani, V. Epidemiology of neoplastic eyelid lesions in tertiary care hospital. Indian Journal of Pathology and Oncology. 2018;5(1):67-74.
2. Mondal SK, Dutta TK. Cytohistological study of eyelid lesions and pitfalls in fine needle aspiration cytology. Journal of Cytology. 2008;25(4):133-7.

3. Sheikh IY, Shah FR, Gandhi MB, Shan CK, Shah NR, Ophthalmic neoplastic lesions. A retrospective study of 4 years. Gujarat Medical Journal.2012;67 (2): 53-7.

4. Kumar R, Adhikari R, Sharma M, Phokharel D, Gautam N. Patterns of ocular malignant tumors in Bhairahwa, Nepal. The Internet Journal of Ophthalmology and Visual science . 2008;7(1):1-6.

5. Sanjay CC, Shan SJ, Patel AB, Rathod HK, Surve SD, Nasit JG, A histopathological study of ophthalmic lesions at a teaching hospital. National $\mathrm{J}$ Medical Research. 2012;2(2):133-6.

6. Al-Faky YH. Epidemiology of benign eyelid lesions in patients presenting to a teaching hospital. Saudi J Ophthalmol. 2012 Apr; 26 (2):211-6. doi: 10.1016/j. sjopt. 2011. 05.005. Epub 2011 May 30.

7. Gupta P, Gupta RC, Khan L. Profile of eyelid malignancy in a Tertiary Health Care Center in North India. J Cancer Res Ther. 2017 Jul-Sep;13(3):484-486. doi: 10.4103/0973-1482.183215.

8. Mohan BP, Letha V. Profile of eye lid lesions over a decade: a histopathological study from a tertiary care center in South India. Int J Adv Med 2017;4:1406-11.

Pathology Update: Tropical Journal of Pathology \& Microbiology Available online at: www.pathologyreview.in 590 | P a g e 


\section{Original Research Article}

9. Abdi U, Tyagi N, Maheshwari V, et al. Tumours of eyelid: a clinicopathologic study. J Indian Med Assoc. 1996 Nov; 94(11):405-9, 416, 418.

10. Tesluk GC. Eyelid lesions: incidence and comparison of benign and malignant lesions. Ann Ophthalmol. 1985 Nov;17(11):704-7.

11. Obata H, Aoki Y, Kubota S, et al. [Incidence of benign and malignant lesions of eyelid and conjunctival tumors]. Nippon Ganka Gakkai Zasshi. 2005 Sep;109 (9): 573-9.

12. Mihaela-Cristiana Coroi, Elena Rosca, Gabriela Mutiu, T. Coroi, Marinela Bonta. Eyelid tumors: histopathological and clinical study perfomed in County Hospital of Oradea between 2000-2007. Romanian Journal of Morphology and Embryology. 2010;51(1): $111-5$

13. Sean Paul, Dat TVo, RonaZ, Silkiss. Malignant and benign eyelid lesions in San Franscisco: Study of a diverse urban population. American Journal of Clinical Medicine. Winter2011;8(1):40-46

14. Ho M, Liu DT, Chong KK, et al. Eyelid tumours and pseudotumours in Hong Kong: a ten-year experience. Hong Kong Med J. 2013 Apr; 19 (2):150-5.

15. Ramya BS, Dayananda SB, Chinmayee JT, Raghupathi AR. Tumors of the eyelid- A Histopathological Study of 86 cases in a Tertiary Care Hospital. International Journal of Scientific and Research Publications,2014;4(11):1-5

16. Huang YY, Liang WH, Tsai CC, Kao SC, Yu WK, Kau HC, Liu JL. Comparison of the clinical characteristics and outcome of Benign and Malignant Eyelid Tumors: An analysis of 4521 Eyelid tumors in a Tertiary Medical Centre. Bio Med Research International. 2015. doi : 10.1155/2015/453091
17. Anandini GM, Parikh SB, Shah NR. Histopathological Study of Eyelid Lesions. National Journal of Laboratory Medicine. 2018;7(1):07-11

18. Jahagirdar SS, Thakre TP, Kale SM,et al. A clinicopathological study of eyelid malignancies from central India.Indian J Ophthalmol. 2007 Mar-Apr;55(2):109-12

19. Fouzia Farhat, Qamar Jamal, Mahmood Saeed, Zia Ghaffar. Evaluation of Eyelid Lesions at a Tertiary Care Hospital, Jinnah Postgraduate Medical Centre (JPMC), Karachi. Pak J Opthalmol 2010;26(2):83-6

20. Kale $\mathrm{SM}^{1}$, Patil SB, Khare N, et al. Clinicopathological analysis of eyelid malignancies - A review of 85 cases. Indian J Plast Surg. 2012 Jan;45(1):22-8. doi: 10.4103/0970-0358.96572.

21. Kafle, S., Khadka, D., Karki, S., \& Lavaju, P. (2016). Spectrum of ocular malignant tumors in a tertiary care teaching hospital. Journal Of Patan Academy Of Health Sciences, 2016; 3(1), 15-17

22. Gupta Y, Gahine R, Hussain N, et al. ClinicoPathological Spectrum of Ophthalmic Lesions: An Experience in Tertiary Care Hospital of Central India. J Clin Diagn Res. 2017 Jan; 11(1): EC09-EC13. doi: 10.7860/JCDR/2017/23589.9230. Epub 2017 Jan 1.

23. Wang JK, Liao SL, Jou JR, et al. Malignant eyelid tumours in Taiwan. Eye (Lond). 2003 Mar;17(2):21620. DOI:10.1038/sj.eye.6700231

24. Kaliki S, Ayyar A, Dave TV, Ali MJ, Mishra DK, Naik MN (2015) Sebaceous gland carcinoma of the eyelid: clinicopathological features and outcome in Asian Indians. Eye (Lond) 2015; 29(7):958-963

25. Lin HY, Cheng CY, Hsu WM, et al. Incidence of eyelid cancers in Taiwan: a 21-year review. Ophthalmology. 2006 Nov;113(11):2101-7. Epub 2006 Sep 7.

\section{How to cite this article?}

Giri Punja M, Bharathi M, Shashidhar H.B. Histomorphological spectrum of eyelid lesions-A 6 year retrospective study. Trop J Path Micro 2018;4(8):586-591.doi:10.17511/jopm.2018.i08.07. 